\title{
The Supreme Federal Court as Queen of Chess: Partisan Fragmentation and Judicial Empowerment in Brazil
}

\begin{tabular}{l} 
Revista de \\
Sociologia \\
e Política \\
\hline
\end{tabular}

DOI 10.1590/1678-987320287307en

\author{
Leon Victor de Queiroz Barbosa' (iD), Ernani Carvalho' \\ 'Political Science Department, Federal University of Pernambuco, Recife, PE, Brazil.
}

\begin{abstract}
Introduction: This article deals with the Supreme Federal Court's empowerment trajectory, exploring exogenous variables in order to explain what made the Supreme Court so institutionally powerful, and how it happened. After the classic studies on the global expansion of the judicial power, that pointed to a myriad of causes as a result of the phenomenon, several recent researches have indicated the political-party fragmentation as the main cause of judicial empowerment. Seeking to corroborate these analyses, the present work analyzes the institutional empowerment of the Brazilian Judiciary from 1945 to 2015, testing the hypothesis the greater the party fragmentation, more institutional power the STF holds. Materials and Methods: As a dependent variable, a synthetic indicator was created to measure the institutional power of the Federal Supreme Court year by year. The independent variables measure the party composition of the Chamber of Deputies annually for the same period. In addition to these variables, other measures were imported from the $\mathrm{V}$-Dem database. For this analysis, simple linear, generalized linear and multinomial models were used. Results: We identified significant impact of party fragmentation on institutional empowerment of the Supreme Court. In all tests, party fragmentation increased the chances of institutional empowerment of the Brazilian judiciary. Discussion: The exogenous reforms that generated this empowerment took place with the support of the Executive and the leniency of the Legislative, transforming the Brazilian Supreme Court into the Queen of the Chess.
\end{abstract}

KEYWORDS: Judiciary Power; Partisan Fragmentation; judicial empowerment; Supreme Federal Court; multinomial; factorial analysis.

Received in September 7, 2018. Approved in June 14, 2019. Accepted in February 27, 2020.

\section{Introduction ${ }^{1}$}

${ }^{1}$ This research was supported by Nacional Council for Scientific and Technological Development - CNPq, and the Coordination for the Improvement of Higher Education Personnel CAPES. We thank the anonymous reviewers of the Revista de Sociologia e Politica for their comments on this article.

${ }^{2}$ See the exemplary decision of that Court in the Marbury v. Madison case.
$\mathrm{D}$ uring the development and improvement of modern democracies, attention was focused on Representative Power. The Legislative Body has always been the vector of legitimacy and sovereignty, that is, the apex of the very idea of democratic government. Since the incremental reforms in the English model, there has been an increasing improvement in Parliament, whose power was gradually shared with the Monarchy until its current institutional design, under the aegis of the principle of parliament's sovereignty, that is, the Legislative has the last word.

In contrast to the British model, Madison developed a system of checks and balances where the Legislative would be separate from the Executive and judges allocated in a higher court would control the other powers through the exegetical application of the Constitution. In other words, the sovereignty of the parliament would give way to the supremacy of the constitution. Under the aegis of this principle, Madison and Hamilton, with a strong participation of the American Supreme Court itself ${ }^{2}$, designed a model that gave the Judiciary the last word in the decision-making process, through judicial review. The common law system itself contributed to the establishment of the American Supreme Court, and, especially after the Marbury v. Madison case, the limits and scope of its activities within the framework of the other powers' act review.

This model of control by judges proved to be quite effective and widespread in the period after the second war, because it was able to inhibit the majority 
${ }^{3}$ There are countless works that demonstrate this assertion, we would highlight those of Sweet (2000), David (2002) and Maravall \& Przeworski (2003).

${ }^{4}$ The former Supreme Court of Justice, from the imperial era of Brazil, was renamed Supreme Federal Court with the provisional constitution, through Decree 510, of June 22,1890 . For a view of the differences and merging of the models see Carvalho (2007). ${ }^{5}$ For the sake of illustration, we suggest reading Barbosa (2015), which deals with the institutionalization of judicial review in the Brazilian system.

${ }^{6}$ For more details see Rae (1971).

${ }^{7}$ We highlight the two most important ones: Marbury v. passions, preventing dangerous, but legislatively majority politicians, from gaining power, as in the case of Germany in the Nazi period. Thus, the classic collection by Tate \& Vallinder (1995) was the first academic effort aimed at understanding the causes and consequences of this process, which had gained global dimensions. In other words, with regards to Western democracies, parliamentarians were no longer the last word in the decision-making process, more and more judges were playing a central role in this dynamic. It is a segment with strong political and social ascension, specially selected to compose a judicial body with special competence ${ }^{3}$.

Brazil followed this global movement of Judiciary expansion and by 1988, in its constitutional design, combined two models of judicial review, the American model and the concentrated Kelsenian model, which in the original design was exercised by an administrative body outside the three powers, but in Brazil it ended up in the hands of the same body that was responsible for the North American type of review. This is how the current Supreme Federal Court (STF) ${ }^{4}$ emerged. However, this model did not appear randomly or accidentally. The national record of democratic disruptions and political instability would play a major role in empowering our supreme court ${ }^{5}$. The main question of this research is directed to how and why the Supreme Court became so powerful. Who provided the STF with more power, the Executive or the Legislative? What effect does the political regime have on this increase in power? The main hypothesis is that political party fragmentation has made the Legislative and Executive endow the STF with sufficient power to protect elites who leave power, as well as avoid congressional gridlocks, endowing the supreme court with the capacity to resolve decision impasses in order to guarantee the fluidity of the political system, removing decision paralysis.

To test these hypotheses, a database was set up comprehending the years between 1945 and 2015, where each year is an event and in which seventeen exogenous variables are measured, among which we highlight five indicators of institutional empowerment of the STF and the Judiciary, three measures for party fragmentation through the effective number of parties (NEP - from the term in Portuguese "Número Efetivo de Partidos"), the minimum number of parties to implement constitutional change (NMP - from the term in Portuguese "Número Mínimo de Partidos") and the Douglas Rae fractionalization index $(\mathrm{F})^{6}$, as well as two variables of political competition (polyarchy and political competition) and a control binary variable for political regime. Interactive terms were also created to capture the marginal effects of the regime. Thus, the article is divided into three sections, after that introduction (I). In the second section, we go through a brief analysis of the evolution of the judiciary in general, and in Brazil in particular. In the third section we return to the institutional debate and explore the data, and in the fourth one we run the models and deliver the analysis. Finally, we bring the conclusions (V) and final considerations.

\section{Summary of the Evolution of the Judiciary Power}

In the year 1752, Montesquieu recorded within three powers the Judiciary is, to some extent, close to nothing. His work, the classic The Spirit of the Laws, would become a landmark in the theory of the separation of powers. In fact, Judges did not occupy a prominent place in the construction of models of democracy, either in Classical Antiquity or in the post-absolutism period. Not even James Madison in his federalist articles had thought of giving the Supreme Court so much prominence, which, in his institutional design, operated as a mechanism for checks and balances within the federative-presidential logic of the North American model. It was a set of judicial decisions ${ }^{7}$ that built, through precedent, the strength that the American Constitutional Court started to exert 
Madison in 1803 and Lochner v. State of New York in 1905.

${ }^{8}$ The debate can be found in Herrera 1994.

${ }^{9}$ For more on the Sovereignty of Parliament principle, see Koopmans (2003). over other powers. These cases were seminal, not only to reinforce checksand-balances, but also to illustrate the Supreme Court as a policy maker, as outlined in Robert Dahl's seminal article (Dahl 1957).

While the diffuse North American judicial review model found a favorable environment in the common law system, which allows the Judiciary to innovate in Law through the rule of precedent, the civil law model required a positive institutional design through the Legislative, which in a way prevented the Judiciary from self-empowerment. It was in 1920, in Austria, that Hans Kelsen and Carl Schmitt had an intense debate ${ }^{8}$ about the adoption of a model of judicial intervention that was not as strong as the one of the United States. So the concentrated-ABSTRACT model emerged in Austria, where a body outside the Judiciary, but holding last word on the Constitution, would have as its main prerogative to protect it from conjunctural majorities, seeking to provide legal stability over time. However, this debate only gained worldwide proportions after the Second World War, when European nations found themselves weakened by the Sovereignty of Parliament principle ${ }^{9}$, and sought a model that would protect them from populism and from the appropriate legislative majorities. From then on, the Madisonian institutional design enshrined the Principle of Supremacy of the Constitution, which started to be adopted by several European and Latin American countries. In other words, the Judiciary Power came to be seen within the three powers as a factor of stability against legislative majorities that tended to tyranny of the majority.

This new configuration in the theory of separation of powers endowed the Judiciary with a role previously unheard of, which, by strengthening institutionally the body through constitutional rules, allowed Judges to start to interfere with more force and frequency in the political arena. As Lijphart (2003, p. 258) pointed out, if a body is created with the sole purpose of examining the constitutionality of the legislation, it is very likely that it will perform this task with some vitality. The Brazilian case is even more interesting, since its supreme court, the Supreme Federal Court - STF, is not a body with a single aim in analyze the constitutionality of norms and rules. He also acts as an ordinary appellate body in cases where he is the original body for actions against certain public authorities, in addition to assessing extraordinary appeals, where he exercises diffuse judicial review and also acts as a concentrated judicial reviewer. In other words, the Brazilian model is a hybrid model that united the North American model and the Kelsen model. However, this model was built over time, gradually and incrementally. The STF was not always so powerful, as demonstrated by Aliomar Baleeiro in the work "O Supremo Tribunal Federal, esse outro desconhecido" (The Supreme Federal Court, this other unknown), published in 1968 (Baleeiro 1968). The Graph 1 illustrates this evolution over time. The $y$-axis represents the number of words contained in the section dedicated to the Judiciary in each Constitution by presidential mandates ( $\mathrm{x}$-axis) due to the changes made by constitutions and constitutional amendments. Thus, it was possible to capture the "size" of each of the three powers, allowing their comparison. The graph shows that the year 2004 (Lula 2003-2010) was the moment when the Judiciary (black line) overtook the Legislative (red line). The Executive is represented by the blue line. It was in that year that there was a reform of the judiciary (Amendment 45 of 2004), with the creation of the National Justice Council, making the control of the central Judiciary to become even stronger.

In addition to the reform of the Judiciary, Andrei Koerner stressed that President Lula, upon assuming the Presidency of the Republic in 2003, had difficulties in implementing his agenda through the Legislative route, opting for the judicial route when appointing progressive ministers linked to the left and social movements (Koerner, 2013). This argument is well illustrated in Graph 2, with 
Graph 1 - Branches' Evolution (1891 - 2014)

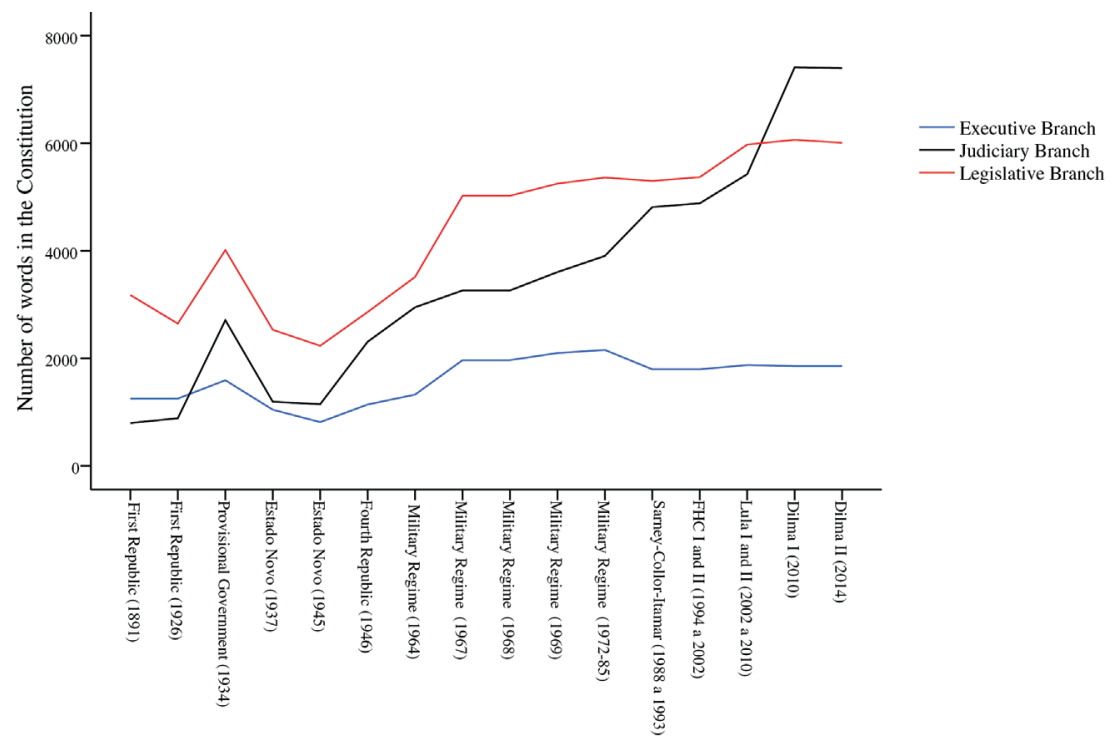

Source: The authors, based on Barbosa 2015.

Graph 2 - Indicator of Judicial Empowerment and Party Fragmentation between 1945 and 2013.

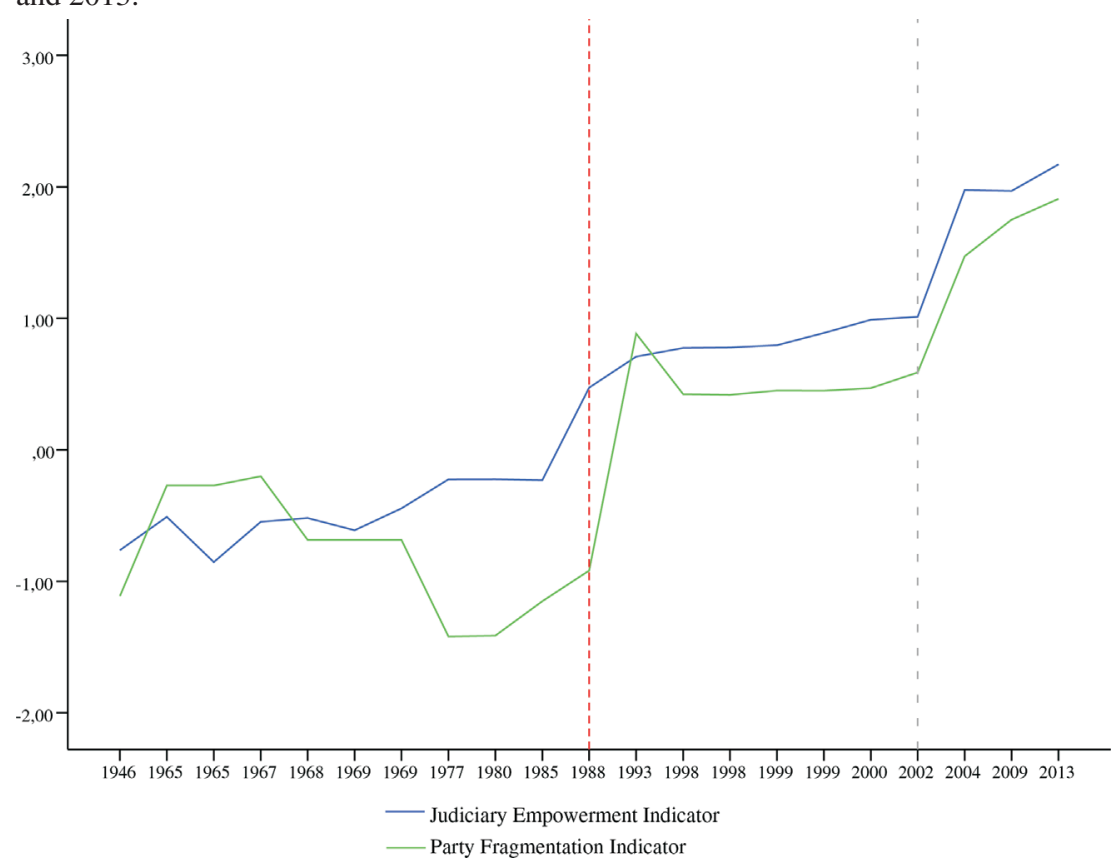

Source: The authors, based on Barbosa 2015.

the alignment of the indicators ${ }^{10}$ of judicial empowerment and party fragmentation. These indicators were constructed through the factor analysis of six variables in two blocks: 1) judicial empowerment, where the variables that measure the size of the Judiciary Power in the Constitution through the number of words (NPPJ), the degree of detail of the constitutional text related to the Judiciary (D) and the STF Empowerment Indicator (iSTF $\left.{ }^{11}\right)$; 2) party fragmentation, in which the variables of the effective number of parties (NEP), the Rae fractionalization index $(\mathrm{F})$ and the minimum number of parties were implemented to implement a constitutional change (NMP). For more details, see Barbosa (2015, p. 63-98).
${ }^{11}$ This indicator will be further detailed below, in the methodology section.
${ }^{10}$ For more details, see Barbosa (2015, pp. 63-98). 
In the Graph 2, the y-axis is represented by the factored indicators, while the $\mathrm{x}$-axis represents the year of constitutional changes (by Constitution and by amendments). The red dotted line signifies the point of no return, that is, after the 1988 Constitution there is no way for the Executive and/or Legislative to go back and diminish the powers of the Judiciary, unless it agrees with this reduction, which is very unlikely. Once the STF is in charge of controlling constitutional changes, any attempt to reduce its power through a Constitutional Amendment will be up to it to decide on its own reduction of power. This event specifically shows that, within the current constitutional order, it is the STF that decides on its own powers, being responsible for making a self-restraint (Graph 1 shows that there is no reduction of power after 1988). The gray dotted line, on the other hand, illustrates Koerner's 2013 argument, exactly when the indicators of party fragmentation and judicial empowerment are aligned over time. This alignment suggests an extremely strong correlation between party fragmentation and judicial empowerment.

The 1988 Constitution ignored Kelsen's concern to create a judiciary as powerful as that of the United States. And it went further, incorporating a softer model, but which in the Brazilian institutional design became extremely strong, since in Kelsen's conception, concentrated control should be exercised by an administrative body outside the three powers and not by the Judiciary, as it is in Brazil. Thus, the Brazilian model makes the Federal Supreme Court (from a prescriptive-normative point of view) an institutionally extremely powerful body. However, having the institutional power to act does not guarantee it will do so (contrary to Lijphart's argument). As in national model the Judiciary is inert, it is necessary that other bodies first provoke it. And these demands have in fact been gaining strength as the STF responds to them with what jurists call judicial activism.

But what makes an elected political power to allow an unelected power to interfere with its actions in such a define way? Why does the Legislative and/or Executive endow the Judiciary with such strong institutional power (normative power)?

\section{II.1 Political Uncertainty and the Insurance Model}

${ }^{12}$ In Portuguese: Madison insistiu que o espírito das facções pode ser perigoso à liberdade e, mais adiante, à democracia. Ele também reconheceu, entretanto, que em uma república, facções e partidos, que servem mais adiante a interesses públicos e privados, não podem ser abolidos sem minar o próprio
John Ferejohn (2002) uses the Madisonian institutional design to argue that the political space used for political criticism and contestation can suffer various forms of abuse in order to threaten the very operationalization of democracy. According to Ferejohn

Madison insisted that the spirit of faction can be dangerous to liberty and therefore, ultimately, to democracy. He also recognized, however, that in a republic, factions and parties, which serve to further both public and private interests, cannot be abolished without undermining republican government itself. At best, the politics of faction and party can be regulated or managed to limit the likely abuses. The most satisfactory form of regulation relies on the electoral process to correct political pathology. Of course, if democratic self-regulation fails, there are court-enforced constitutional safeguards that may be employed to limit abusive lawmaking (Ferejohn 2002, p. 50) ${ }^{12}$.

Ferejohn argues that, in contrast to the previous argument, the law or its application must occur within courts. Its application is controversial, but it is to be expected that in most cases, it is a technical matter of finding the correct principles under which the dispute is established. The duty of judges is to promote fair and non-biased courts before conflicting political parties can settle their disputes under previously established legal rules (Ferejohn 2002, p. 50). This model, continues Ferejohn, sees the courts as places where specific disputes are fought, not as an arena where general regulations are formulated. In other 
governo republicano. $\mathrm{Na}$ melhor das hipóteses, as políticas das facções e dos partidos podem ser reguladas ou dirigidas de forma a limitar a probabilidade de abusos. A forma mais satisfatória de regulação reside no processo eleitoral para corrigir patologias políticas. É claro que, caso as autorregulações democráticas falhem, há os tribunais constitucionalmente empoderados como salvaguarda que pode ser empregada para limitar abusos no processo legislativo (Ferejohn, 2002, p. 50, translated by the authors) words, a Supreme Court as an effective mechanism to prevent the tyranny of the majority or popular passions, as Jon Elster (2000, p. 156) pointed out, would become just one of its functions. Ferejohn offers two responses to this increase in the scope of the Judiciary (judicialization of politics).

The first refers to the increase in the fragmentation of power within political powers, which limits the ability to legislate, or to be the place where public policies can be effectively formulated, that is, what Ferejohn calls the fragmentation hypothesis: when political powers cannot act, people who seek to resolve their conflicts will tend to gravitate towards institutions that can deliver solutions. The institutions that can offer this solution are the courts, especially where the legislature is divided (Ferejohn 2002, p. 55). The second concerns the expectation that some courts can be trusted to protect a wide range of important values against potential political abuse. This is the legal hypothesis.

But what leads the constituents to include in the constitutional text judicial review mechanisms, capable of reviewing future legislative acts? According to Ginsburg (2003, pp. 24-25), this depends on the positions of power of the constituents in post-constitutional governments, and the key factor they take into account is the uncertainty, at the moment of constitutional construction, of the future configuration policy. Ginsburg outlines two extreme scenarios that reinforce this argument. The first concerns a one-party scenario, where there are very few incentives to establish a neutral arbitrator to resolve disputes. The second concerns a scenario of many political forces, where no party is confident that it will remain in power in the next elections. When political forces are deadlocked or dispersed, no party can predict who will win the elections after the implementation of the Constitution. In other words, if there is no political party confident in the possibility of electoral victory, they will all prefer to limit the majority, and later, they will value minority institutions, such as judicial review. Ginsburg called this reasoning an insurance model of judicial review. In other words, the judicial review operates as an insurance policy against impasses and dispersions of political parties in the decision-making arena.

The literature that addresses the theme of institutional construction points to other explanatory forms of this phenomenon (Ingram 2015). Despite the strength of the insurance model, which has a strong influence in countries of recent transition, as is the case in Brazil, it must be recognized that it is not sovereign. It is feasible to point out flaws in the argument that declining elites would have the strength to empower institutions in order to minimally preserve their interests (Ingram 2016). "Likewise, the argument centered on the uncertainty arising from the increase in electoral competition is not able to explain the timing and content of these reforms" (Da Ros 2017, p. 61).

The so-called internal actors (members of the Judiciary) can also play a fundamental role in the formulation of these changes. They directly benefit from the strengthening of the courts, including, in some cases, overcoming the strength of the declining elites (Couso et. al. 2010). Although we recognize the relevance and importance of competing theoretical explanations, we insist that, for the Brazilian case, the evidence of the insurance model gains prominence in the works that deepened the modus operandi of constitutional building.

The influence of so-called legal actors in the process of achieving the Constitution is a peaceful point within Brazilian literature. However, this does not mean that there were no mediations built during the manufacturing process of the Constitution. In this case, the PMDB party was strongly favored by the principle of party proportionality, since, in addition to having the majority of the constituents $(54,20 \%$ of the total), it had in its favor a flexible principle for the occupation of prominent positions. The eight reporting roles of the commissions were occupied by PMDB members, in flagrant disregard for the principle 
of party proportionality. In addition, PMDB was responsible for the reporting in thirteen subcommittees and for the chairmanship of another fifteen.

Without going too far into the issues of the 1988 Constituent process, it is clear that the elite that negotiated the transition was not the decadent one. PMDB was the main opposition party to the regime and birthed all negotiations related to society's pressure groups (Coelho 1999). This was no different in the case of judicial empowerment.

If during the constituency there were no major difficulties in converging the Madisonian and Kelsenian models of control over normative acts, the subsequent period also did not show any difficulties. Since the Ginsburg argument is for periods of constitutional building, it is in constitutional changes that most attention resides, since, as Melo 2007 said, it is not difficult to modify the Constitution, so the argument gains strength not only at each constitutional period, but with each amendment that modified the Judiciary itself. From 1891 to 2013 there were 29 modifications, seven by constitutions and 22 via constitutional amendments. Within these 22 amendments, ten $(45,5 \%)$ were authored by the Legislative and twelve $(54,5 \%)$ were authored by the Executive (all exogenous). The following graph illustrates the increase in the Judiciary's power from 1891 to 2015.

It is evident that democratic governments contributed much more to the slope of the adjustment line than dictatorial governments (as illustrated in the Graph 3), which corroborates Ginsburg's argument. This will be made even clearer in section 4, where the data will provide even more robust responses. So far, both Ginsburg and Ferejohn have made a solid contribution to formulating the hypothesis that the greater the party fragmentation, the greater the empowerment of the judiciary.

\section{Methodology, methods and data}

The institutional changes implemented by the constitutions and their respective amendments were not random or bequeathed to chance, they were the result of a strategic calculation that took into account the very trajectory of the Brazilian political system. The institutional aspect is pressing in this analysis, since it analyzes what the institutions do, how they maintain themselves and how the actors behave. There are, therefore, two perspectives under which one takes into account, first a strategic calculation and second, the cultural aspects. Hall \& Taylor (2003) argue that the individual's behavior is never entirely strategic, being limited by his worldview, that is, for culturalists individuals seek more satisfaction than optimization. The perspective of strategic calculation goes in the opposite direction, showing that institutions are maintained because they do something close to the Nash Equilibrium. Historical institutionalists, on the other hand, work with both perspectives when dealing with the relationship between institutions and action. According to Victoria Hattam (1993), the difference between institutional contexts has a direct impact on power relations.

\section{III.1 Creation of the iSTF indicator}

\footnotetext{
${ }^{13}$ For iSTF, Barbosa 2015 chose not to establish a scale, but to maintain a counting pattern, mainly due to the generalized linear models, being the most appropriate scale for the negative binomial model, as shown by Nelder \& Wedderburn (1972).
}

We adopted the dependent variable iSTF, developed by Barbosa $2015^{13}$, which is an indicator based on Shugart \& Carey (1992) - who created an index of institutional powers for the President of the Republic from two dimensions, one is the power to legislate and the other concerns non-legislative powers, on a scale from zero (weak) to 4 (strong), in each dimension. Therefore, the dependent variable iSTF, can be represented by the following formula: $i S T F=p(A A)+$ $\boldsymbol{j}(\boldsymbol{g A P})$, the term $p$ means the active procedural capacity, that is, the ability to act 
Graph 3 - Dispersion of Judiciary's Number of Words by Presidential Mandate between 1891 and 2015.

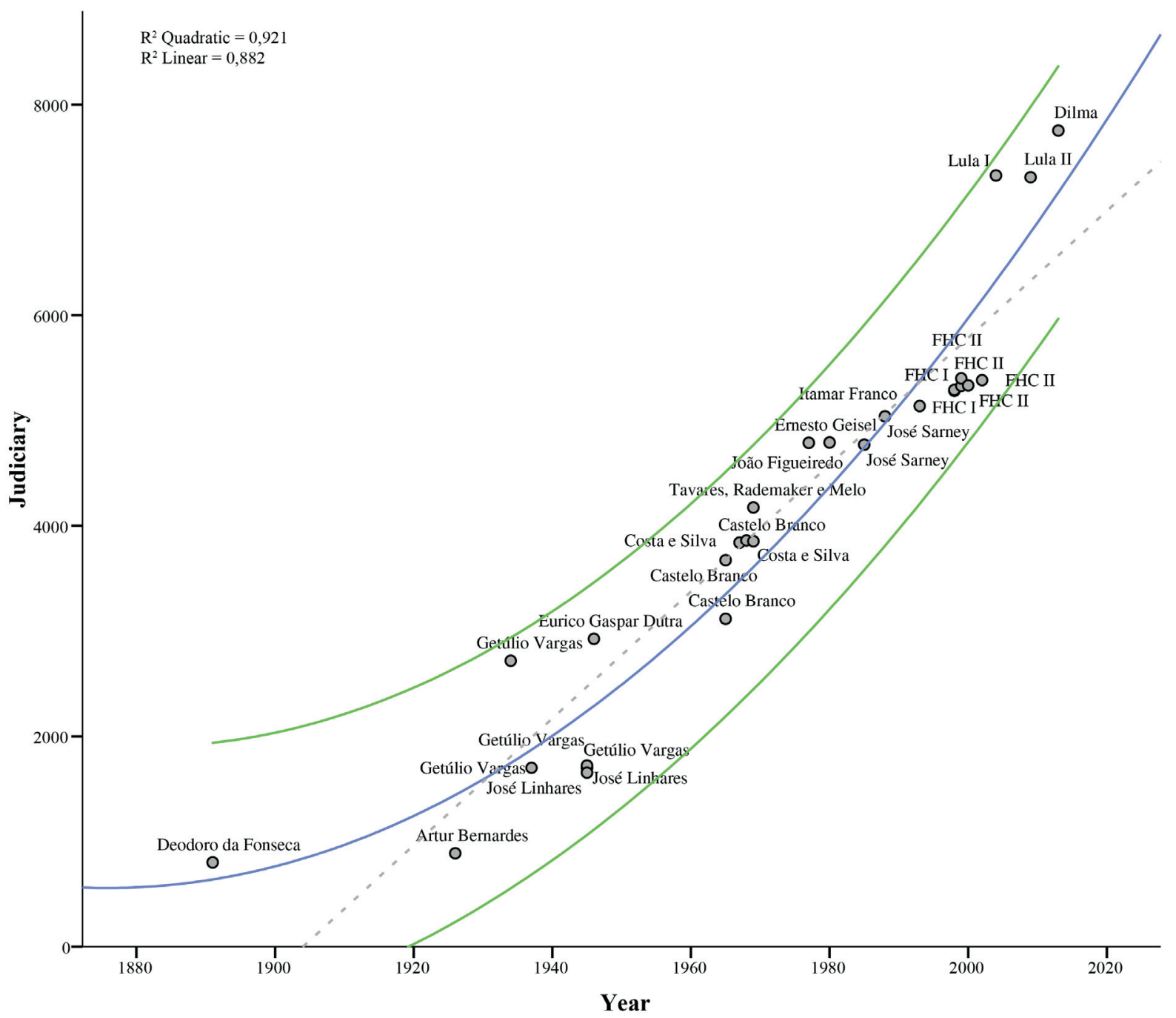

Source: The authors, based on Barbosa 2015.

Note: The variable used on the x-axis of Graph 3 is the number of words of the judiciary (NPPJ), and the y-axis represents 25-year intervals, with the mandates of the presidents of the republic highlighted within the image. Thus, it is possible to show under which presidents there was a greater inclination in the empowerment of the judiciary through the number of words as a proxy for judicial empowerment.

by provoking an author with procedural legitimacy active $A A^{14}$. The term $j$ means the prerogative of judging actors constitutionally authorized to appear on the passive pole, whether in a group or individually $g A P^{15}$. This way, the agents that can sue are counted, together with the agents that can be sued, forming a set of institutional powers that authorize the STF to act in the most varied scenarios, as in diffuse/concentrated control and even in originary actions against public authorities, such as the President of the Republic, Parliamentarians and the highest echelons of the Cabinet. This indicator, therefore, measures the judicial empowerment of the Supreme Federal Court.

\section{III.2 Description, Sources and Measurement of Variables}

In addition to the iSTF, we highlight two independent variables, henceforth exogenous, to capture party fragmentation: Effective Number of Parties in the Chamber of Deputies (NEP), and the Minimum Number of Parties (NMP) to implement a constitutional change (as an alternative to NEP). This measure was 
${ }^{14}$ These actors with proc These actors with active procedural capacity are listed in art. 103 of the Federal Constitution of Brazil, and they are: I - the President of the Republic; II the directing board of the Federal Senate; III - the directing board of the Chamber of Deputies; IV - the Directing Board of a State Legislative Assembly or of the Federal District Legislative Chamber; V - a State Governor or the Federal District Governor; VI - the Attorney-General of the Republic; VII - the Federal Council of the Brazilian Bar Association; VIII - a political party represented in the National Congress; IX - a confederation of labour unions or a professional association of a nationwide nature.

${ }^{15}$ Here are counted all the authorities that can be tried by the STF, as stated in the Federal Constitution of Brazil. ${ }^{16}$ In Portuguese: Se um partido controla $75 \%$ das cadeiras, o número mínimo de partidos para aprovar mudanças constitucionais será um, seja maioria absoluta ou qualificada. Entretanto, se a Casa Legislativa é composta por cinco partidos compartilhando 49, 16, 13, 12 e $10 \%$ das cadeiras, o número mínimo de partidos requerido para aprovar mudanças na Constituição será dois ou três, a depender da regra de emendamento (Negretto 2013, p. 85 , translated by the authors)

${ }^{17}$ The institutional power here is understood as Barbosa (2015) proposed, that is, it is a power described in the rules of the game (precisely the Constitution), it is not a power utilized (whose variables would not be institutional, but decisional, analyzing the decisions of the court). More specifically, it is a de jure power, that is, of being able to act. And the power to act interferes in the calculation that legislative actors make when making decisions, within the decision-making process.

${ }^{18}$ For a more detailed explanation see Linzer \& Staton (2015, p. 225).

${ }^{19}$ For a more detailed explanation, see Coppedge $e t$. created by Negretto 2013, to capture the exact number of parties with influence to implement constitutional changes, a situation that the NEP does not capture. In this sense, Negretto proposes the NMP as the size of the "reform coalition": a discrete variable indicating the minimum number of parties necessary to form a coalition able to pass constitutional amendments. For him,

\begin{abstract}
If one party controls 75 percent of the seats, the minimum number of parties to pass constitutional changes will be one, whether under absolute or qualified majority. If, however, the constituent body is composed of five parties sharing, say, $49,16,13,12$ and 10 percent of the seats, the minimum number of parties required to pass constitutional changes is either two or three depending on whether the decision rule is absolute or two-thirds (Negretto 2013, p. 85) ${ }^{16}$.
\end{abstract}

Thus, both NEP and NMP will be considered independent variables and used separately, since there is a strong correlation between them, which generates multicollinearity if they are present in the same model. In addition to these variables, we also use others based on Linzer \& Staton 2015 and some from the Varieties of Democracy (V-DEM) dataset. The relationships between variables are described below. The first four variables are dependent, the first being the iSTF indicator followed by Linzer \& Staton 2015 variables. The variables after the NEP are the independent ones and seek to measure political party fragmentation (NEP, NMP, F, Polyarchy and Political Competition). These last two were extracted from the Varieties of Democracy (V-DEM) dataset for the years under analysis. Regime is a binary variable measured to determine democratic (1) and authoritarian (0) periods, facilitating the creation of interactive terms capable of showing the marginal effect of political and party fragmentation in such periods. The iSTF synthetic indicator measures the number of prerogatives that the Federal Supreme Court has had over time, ranging from diffuse control of constitutionality to the concentrate, through the number of actors that can trigger such a judicial review mechanism, as well as by the authorities subject to Supreme Court, seeking to measure its institutional power ${ }^{17}$. The variable $\mathrm{LJI}^{18}$ stands for Latent Judicial Independence and seeks to measure a unified measure for two hundred countries from 1948 to 2015 (Linzer \& Staton 2015, p. 224). The XCONST variable is based on the Polity IV project and was designed to measure the extent to which decisions constrain the executive's discretionary power (Linzer \& Staton 2015, p. 226). For statistical purposes, we recalculate this variable and create the variable XCONST_cat, an ordinal variable of three categories: weak (0 to 2), medium ( 3 and 4 ) and strong (5 and 6). The Polyarchy variable $^{19}$ (v2x_polyarchy) is an indicator that measures five components: "elected incumbents", "free and fair elections", "freedom of expression", "freedom of association" and "inclusive citizenship" (Teorel et. al. 2016, p. 2). It is intuitive to say that the higher the level of Polyarchy, the greater the level of political competition, and the greater the level of uncertainty due to party fragmentation, leading to judicial empowerment as a way of guaranteeing the limits of the political game. Finally, we used an exclusive variable for political competition (e_polcomp) from the V-Dem dataset (Coppedge et. al. 2017a). The following tables (Table 1) show the statistical descriptions of the variables used.

The period of anylisis is from 1945 to 2015, with the exception of Linzer \& Staton (2015) variables, which are only available from 1948 to 2015, and the political competition variable, from V-DEM, which begins in 1946. In addition to the variables described in Table 2, we also used others from the V-Dem dataset, such as the Judicial Constraints on Executive Index (v2x_jucon) as well as the variables used for its calculation such as compliance with judiciary (v2jucomp), compliance with high court (v2juhccomp), high court Independence index (v2juhcind), and lower court Independence index (v2juncind). These indicators also measure the strength of the Judiciary. It was necessary to measure the relationship that the variables have among themselves, in order to 
Table 1 - Statistical Description of Variables

\begin{tabular}{lccccc}
\hline & N & Min & Max & Mean & Standard deviation \\
\hline iSTF & 71 & 39 & 137 & 78.70 & 36.519 \\
LJI & 65 & 0.0798 & 0.6378 & 0.4028 & 0.18106 \\
XCONST & 65 & 0 & 6 & 4.06 & 2.157 \\
XCONST_cat & 65 & 1 & 3 & 2.31 & 0.934 \\
Competição Política & 69 & 1 & 9 & 5.2873 & 3.183 \\
NEP & 71 & 1.66 & 13.45 & 3.06 & 3.20177 \\
NMP & 71 & 1 & 9 & 0.8173 & 2.833 \\
F (Rae) & 71 & 0.501 & 0.956 & 0.5345 & 0.18145 \\
Poliarquia & 71 & 0.150 & 0.892 & 0.68 & 0.28160 \\
Regime & 71 & 0 & 1 & & 0.471 \\
N Valid (listwise) & 64 & & & \\
\hline
\end{tabular}

Source: The authors with data from Barbosa 2015, Linzer \& Staton 2015 and Coppedge et. al. 2017a.

al. (2017b, p. 49), and Teorell et. al. (2016). avoid multicollinearity problems and to evaluate the use of a factor analysis to use transformed variables in order to reduce the number of variables used. On the next tables are the correlation matrices between the variables (Tables 2 e 3 ).

The first five variables were collected from the Varieties of Democracy (V-DEM) dataset for the period 1945-2015, measuring independence and judicial strength in constraining the Executive. As they are extremely correlated with each other, it is more appropriate to reduce them to a single factor through factor analysis. We will call this unique factor the Judicial Indicator from V-DEM. In the other independent variables (NEP, NMP, F, Polyarchy and Political Competition), which have already been previously explained, it is possible to verify an extremely high and significant correlation (except for the Fragmentation Indicator, which is the result of the factor analysis and carries a high load of variance of all other independent variables). In other words, the one-factor factorial analysis proved to be quite right to aggregate this information and facilitate a single model of ordinary least squares - OLS. The factor analysis is described in the table below.

Due to this association between variables, the ideal thing to do is a factor analysis. According to Hair et. al. (2005, p. 89), “ factor analysis can be utilized to examine the underlying patterns or relationships for a large number of variables and to determine whether the information can be condensed or summarized in a smaller set of factors or components." This type of analysis is a multivariate technique of statistical methods, whose purpose is to define the underlying structure in a data matrix (Hair et. al. 2005, p. 91). The independent variables also follow the same correlation pattern as shown below. The extraction method is that of principal components with varimax rotation with 25 interactions by convergence. The factor was saved by a regression method whose variable will be standardized, as will be seen later.

Figueiredo Filho \& Silva Júnior (2010) didactically establish three stages of planning a factor analysis. First, there are four assumptions to be satisfied: 1) minimum number of cases between 50 and 100 and the ratio of 5 cases for each variable. Although there are not 100 cases, which, according to Hair et. al. (2005), would be ideal for a more robust result, the ratio between the number of cases and the number of variables must be greater than five to one. Thus, with 29 events and three variables, this assumption was satisfied. 2) the correlation coefficients between the variables must be above 0,30 . For both correlation ta- 
Table 2 - Pearson's Correlation Matrix Between Dependent and Independent Variables

\begin{tabular}{|c|c|c|c|c|c|c|c|c|c|c|c|}
\hline & \multicolumn{4}{|c|}{ Dependent Variables } & \multicolumn{7}{|c|}{ Independent Variables } \\
\hline & iSTF & LJI & XCONST & XCONST_cat & NEP & NMP & $\mathbf{F}$ & Polyarchy & Regime & $\begin{array}{c}\text { Political } \\
\text { Competition }\end{array}$ & $\begin{array}{c}\text { Fragmentation } \\
\text { Indicator }^{\mathrm{I}}\end{array}$ \\
\hline \multirow[t]{2}{*}{ iSTF } & 1 & $0.590 * *$ & $0.631 * *$ & $0.501 * *$ & $0.873 * *$ & $0.926 * *$ & $0.421 * *$ & $0.894 * *$ & $0.466 * *$ & $0.680 * *$ & $0.862 * *$ \\
\hline & & 65 & 65 & 65 & 71 & 71 & 71 & 71 & 71 & 69 & 69 \\
\hline \multirow[t]{2}{*}{ LJI } & & 1 & $0.899 * *$ & $0.849^{* *}$ & $0.658^{* *}$ & $0.490^{* *}$ & $0.650 * *$ & $0.842 * *$ & $0.781 * *$ & $0.887 * *$ & $0.808 * *$ \\
\hline & & & 65 & 65 & 65 & 65 & 65 & 65 & 65 & 64 & 64 \\
\hline \multirow[t]{2}{*}{ XCONST } & & & 1 & $0.975^{* *}$ & $0.735^{* *}$ & $0.542 * *$ & $0.789 * *$ & $0.880^{* *}$ & $0.932 * *$ & $0.966^{* *}$ & $0.905^{* *}$ \\
\hline & & & & 65 & 65 & 65 & 65 & 65 & 65 & 64 & 64 \\
\hline \multirow[t]{2}{*}{ XCONST_cat } & & & & 1 & $0.641 * *$ & $0.436^{* *}$ & $0.809 * *$ & $0.788 * *$ & $0.939 * *$ & $0.930 * *$ & $0.827 * *$ \\
\hline & & & & & 65 & 65 & 65 & 65 & 65 & 64 & 64 \\
\hline \multirow[t]{2}{*}{ NEP } & & & & & 1 & $0.834 * *$ & $0.671 * *$ & $0.896 * *$ & $0.628 * *$ & $0.772 * *$ & $0.944 * *$ \\
\hline & & & & & & 71 & 71 & 71 & 71 & 69 & 69 \\
\hline \multirow[t]{2}{*}{ NMP } & & & & & & 1 & $0.394 * *$ & $0.775 * *$ & $0.410 * *$ & $0.591 * *$ & $0.811 * *$ \\
\hline & & & & & & & 71 & 71 & 71 & 69 & 69 \\
\hline \multirow[t]{2}{*}{$\mathrm{F}$} & & & & & & & 1 & $0.661 * *$ & $0.801 * *$ & $0.796^{* *}$ & $0.802 * *$ \\
\hline & & & & & & & & 71 & 71 & 69 & 69 \\
\hline \multirow[t]{2}{*}{ Polyarchy } & & & & & & & & 1 & $0.758^{* *}$ & $0.914 * *$ & $0.966^{* *}$ \\
\hline & & & & & & & & & & 69 & 69 \\
\hline \multirow[t]{2}{*}{ Regime } & & & & & & & & & 1 & $0.881 * *$ & $0.790 * *$ \\
\hline & & & & & & & & & & 69 & 69 \\
\hline \multirow{3}{*}{$\begin{array}{l}\text { Political } \\
\text { Competition }\end{array}$} & & & & & & & & & & 1 & $0.919 * *$ \\
\hline & & & & & & & & & & & \\
\hline & & & & & & & & & & & 69 \\
\hline \multicolumn{12}{|l|}{ Fragmentation } \\
\hline Indicator & & & & & & & & & & & 1 \\
\hline
\end{tabular}

Source: The authors with data from Barbosa 2015, Linzer \& Staton 2015 and Coppedge et. al. 2017a.

** The correlation is significant at the 0.01 (bilateral) level.

I Variable created from factor analysis, as explained on section III. 
Table 3 - Pearson's Correlation Matrix with Disaggregated Judicial Variables and Political and Party Fragmentation

\begin{tabular}{|c|c|c|c|c|c|c|c|c|c|c|c|}
\hline & \multicolumn{5}{|c|}{ Dependent Variables (disaggregated) } & \multicolumn{6}{|c|}{ Independent Variables } \\
\hline & $\begin{array}{c}\text { Judiciary } \\
\text { Constraints on } \\
\text { Executive Index }\end{array}$ & $\begin{array}{c}\text { Compliance } \\
\text { with Judiciary }\end{array}$ & $\begin{array}{c}\text { Compliance } \\
\text { with High } \\
\text { Court }\end{array}$ & $\begin{array}{c}\text { High Court } \\
\text { Independence } \\
\text { Index }\end{array}$ & $\begin{array}{c}\text { Lower Court } \\
\text { Independence } \\
\text { Index }\end{array}$ & NEP & NMP & $\mathbf{F}$ & Polyarchy & $\begin{array}{c}\text { Political } \\
\text { Competition }\end{array}$ & $\begin{array}{l}\text { Fragmentation } \\
\text { Indicator }\end{array}$ \\
\hline \multirow{2}{*}{$\begin{array}{l}\text { Judiciary Constraints } \\
\text { on Executive Index }\end{array}$} & 1 & $0.910^{* *}$ & $0.980^{* * *}$ & $0.889 * *$ & $0.867 * *$ & $0.892 * *$ & $0.819^{* *}$ & $0.683^{* *}$ & $0.976^{* *}$ & $0.909 * *$ & $0.970 * *$ \\
\hline & & 71 & 71 & 71 & 71 & 71 & 71 & 71 & 71 & 69 & 69 \\
\hline \multirow{2}{*}{$\begin{array}{l}\text { Compliance with Ju- } \\
\text { diciary }\end{array}$} & & 1 & $0.851^{* *}$ & $0.832 * *$ & $0.860^{* *}$ & $0.807 * *$ & $0.847 * *$ & $0.481 * *$ & $0.850^{* *}$ & $0.748^{* *}$ & $0.847 * *$ \\
\hline & & & 71 & 71 & 71 & 71 & 71 & 71 & 71 & 69 & 69 \\
\hline \multirow{2}{*}{$\begin{array}{l}\text { Compliance with } \\
\text { High Court }\end{array}$} & & & 1 & $0.823^{* *}$ & $0.800 * *$ & $0.843^{* *}$ & $0.748 * *$ & $0.671^{* *}$ & $0.972 * *$ & $0.912 * *$ & $0.942 * *$ \\
\hline & & & & 71 & 71 & 71 & 71 & 71 & 71 & 69 & 69 \\
\hline \multirow{2}{*}{$\begin{array}{l}\text { High Court Inde- } \\
\text { pendence Index }\end{array}$} & & & & 1 & $0.946^{* *}$ & $0.890 * *$ & $0.898 * *$ & $0.534 * *$ & $0.842^{* *}$ & $0.681 * *$ & $0.868 * *$ \\
\hline & & & & & 71 & 71 & 71 & 71 & 71 & 69 & 69 \\
\hline \multirow{2}{*}{$\begin{array}{l}\text { Lower Court Inde- } \\
\text { pendence Index }\end{array}$} & & & & & 1 & $0.856 * *$ & $0.928 * *$ & $0.470^{* *}$ & $0.803^{* *}$ & $0.638^{* *}$ & $0.834 * *$ \\
\hline & & & & & & 71 & 71 & 71 & 71 & 69 & 69 \\
\hline \multirow[t]{2}{*}{ NEP } & & & & & & 1 & $0.834 * *$ & $0.671 * *$ & $0.896^{* *}$ & $0.772 * *$ & $0.944 * *$ \\
\hline & & & & & & & 71 & 71 & 71 & 69 & 69 \\
\hline \multirow[t]{2}{*}{ NMP } & & & & & & & 1 & $0.394 * *$ & $0.775^{* *}$ & $0.591 * *$ & $0.811^{* *}$ \\
\hline & & & & & & & & 71 & 71 & 69 & 69 \\
\hline \multirow[t]{2}{*}{ F } & & & & & & & & 1 & $0.661 * *$ & $0.796 * *$ & $0.802 * *$ \\
\hline & & & & & & & & & 71 & 69 & 69 \\
\hline \multirow[t]{2}{*}{ Polyarchy } & & & & & & & & & 1 & $0.914 * *$ & $0.966^{* *}$ \\
\hline & & & & & & & & & & 69 & 69 \\
\hline \multirow{3}{*}{$\begin{array}{l}\text { Political } \\
\text { Competition }\end{array}$} & & & & & & & & & & 1 & $0.919 * *$ \\
\hline & & & & & & & & & & & \\
\hline & & & & & & & & & & & 69 \\
\hline $\begin{array}{l}\text { Fragmentation } \\
\text { Indicator }\end{array}$ & & & & & & & & & & & 1 \\
\hline
\end{tabular}

Source: The authors with data from Barbosa 2015 and Coppedge et. al. 2017a.

**. The correlation is significant at the 0.01 (bilateral) level. 
bles, it is clear that this assumption was also satisfied. 3) the Kaiser-MeyerOlklin (KMO) test, which varies between 0 and 1 (the closer to 1 , the better). For Hair et. al. 2005, a KMO of 0.50 is considerably acceptable. 4) Bartlett's Test of Sphericity (BTS) must have a p value $<0.05$. Table 4 , below, shows the coefficients of these two tests both in relation to the dependent variables and in relation to the independent variables (Table 4).

Having overcome this first stage of satisfaction of the assumptions, the second is centered on the factor extraction technique: main components, main factors, image factorization, maximum likelihood factorization, alpha factorization, unweighted least squares and least squares (Figueiredo Filho \& Silva Júnior 2010, p. 167). The authors show that both principal component analysis (PCA) and factor analysis (PA) "seek to produce linear combinations of variables that capture as much of the variance of the observed variables as possible" (Figueiredo Filho \& Silva Júnior 2010, p. 167). Regarding the best technique, the authors show that

For Garson 2009, "principal component analysis is generally preferred for data reduction purposes (translating the space of variables into an optimal factor space), while factor analysis is generally preferred when the objective of the research is to detect the structure data or causal modeling ". According to Hair et al., 2006, in most cases both the ACP and the AF reach the same results if the number of variables exceeds 30 or if the communalities exceed 0.60 for most variables. This article will use the principal component method as it is the most used PALLANT, 2007. (Figueiredo Filho \& Silva Júnior 2010, p. 167, our own translation).

The technique used in this research to reduce these two categories of variables to two factors is that of principal components, by which the total amount of variance that an original variable shares with all other variables included in the analysis is measured. The issue now becomes the number of factors (Table 5).

Here the researcher faces a trade off between parsimony and explanation. The more factors are extracted, the lower the degree of parsimony, however, the greater the total amount of variance by the factors. On the other hand, the less factors are extracted, the greater the degree of parsimony, however, the smaller the total amount of variance carried by the factors. Thus, the optimal solution is to identify the minimum number of factors, which maximizes the amount of total explained variance. (Figueiredo Filho \& Silva Júnior 2010, p. 168, our own translation).

According to these authors, the eigenvalue rule (Kaiser's criterion) suggests that only factors with eigenvalue above 1 should be extracted, since "the factor with low eigenvalue is contributing little to explain the variance in the original variables" (Figueiredo Filho \& Silva Júnior 2010, p. 168, our own translation). For them, the second stage of the factor analysis planning must follow by: 1) type of extraction (which, in the case of this work, is that of the main components); 2) Kaiser's rule, where only factors with eigenvalue above 1 must be extracted; 3 ) the accumulated variance must be above $60 \%$. The fol-

Table 4 - Kaiser-Meyer-Olkin Test (KMO) and Bartlett's Sphericity Test

\begin{tabular}{lcc}
\hline Tests & $\begin{array}{c}\text { Judicial Indicator from } \\
\text { V-DEM }\end{array}$ & $\begin{array}{c}\text { Fragmentation } \\
\text { Indicator }\end{array}$ \\
\hline Kaiser-Meyer-Olkin (KMO) & 0.728 & 0.716 \\
BTS & 0.000 & 0.000 \\
\hline
\end{tabular}

Source: The authors with data from Barbosa 2015 and Coppedge et. al. 2017a. 
Table 5 - Eigenvalues* (Kaiser's Criteria for the use of factorial analysis)

\begin{tabular}{|c|c|c|c|c|c|c|c|}
\hline \multicolumn{4}{|c|}{ Judicial Indicator from the V-DEM } & \multicolumn{4}{|c|}{ Fragmentation Indicator } \\
\hline \multicolumn{2}{|c|}{ Components } & \multicolumn{2}{|c|}{ Initial Eigenvalues } & \multicolumn{2}{|c|}{ Components } & \multicolumn{2}{|c|}{ Initial Eigenvalues } \\
\hline & Total & $\%$ of variance & Cumulative \% & & Total & $\%$ of variance & Cumulative \% \\
\hline 1 & 4.504 & 90.073 & 90.073 & 1 & 3.97 & 79.405 & 79.405 \\
\hline 2 & 0.286 & 5.719 & 95.792 & 2 & 0.667 & 13.331 & 92.736 \\
\hline 3 & 0.156 & 3.123 & 98.915 & 3 & 0.227 & 4.531 & 97.267 \\
\hline 4 & 0.048 & 0.954 & 99.869 & 4 & 0.105 & 2.091 & 99.358 \\
\hline 5 & 0.007 & 0.131 & 100 & 5 & 0.032 & 0.642 & 100 \\
\hline
\end{tabular}

Source: The authors with data from Barbosa 2015 and Coppedge et. al. 2017a.

* Based on Garson (2009), the greater the eigenvalue, the greater the explanatory contribution of the variance of the variables, that is, the greater the eigenvalue, the greater the variance load that the factor accumulates.

lowing tables summarize this data for both dependent and independent variables (Table 6).

Below we show the relationship between the factored variables and the other independent variables. It is possible to verify, therefore, that the relation of a single dependent variable factored with the other independent variables has not been much altered, allowing the use of a simple linear model (OLS) (Table 7).

\section{Formal models and data analysis}

Due to the nature and distribution of variables, to test the hypothesis that the greater the party fragmentation, the greater the judicial empowerment, two inferential statistical techniques were adopted: the negative binomial, which is part of the generalized linear models and the minimal classic ordinary squares (OLS) of simple linear models. The choice of technique was due to the distribution of the dependent variable, which in this case violates the rules of the linear model, the main one being the normal distribution. The generalized linear models seek to face variables that do not have a normal distribution, more precisely, they seek to meet typical distributions of counts. Several studies give theoretical support to the generalized linear models, especially those of Nelder \& Wedderburn 1972, Feigl \& Zelen 1965, Berkson 1944, and Dyke \& Petterson 1952.

The dependent variables are in the first line, followed by the techniques used. The independent variables are in the first column on the left. Three models (in parentheses) were made for each technique. The first model is the unrestricted one, with all independent variables to verify multicollinearity and to seek a more adjusted, more parsimonious model, which we call model 2 , where only the variables that resisted the multicollinearity test (VIF - Variance Inflation Factor) were maintained. The third model, on the other hand, necessarily has the indicator of political party fragmentation as the only independent vari-

Table 6 - Description of factored variables

\begin{tabular}{lccccc}
\hline & N & Min & Max & Mean & Standard deviation \\
\hline Judicial Indicator from the V-DEM & 71 & -1.17919 & 1.97663 & 0 & 1 \\
Fragmentation Indicator & 69 & -1.44771 & 1.65899 & 0 & 1 \\
\hline
\end{tabular}

Source: The authors with data from Barbosa 2015 and Coppedge et. al. 2017a. 
Table 7 - Pearson's Correlation Matrix with factorized dependent variable

\begin{tabular}{|c|c|c|c|c|c|c|c|}
\hline & $\begin{array}{c}\text { Indicator Judi- } \\
\text { cial (V-DEM) }\end{array}$ & NEP & NMP & $\mathbf{F}$ & Polyarchy & $\begin{array}{c}\text { Political } \\
\text { Competition }\end{array}$ & $\begin{array}{l}\text { Fragmenta- } \\
\text { tion Indicator }\end{array}$ \\
\hline \multirow{2}{*}{$\begin{array}{l}\text { IndicatorJudicial } \\
\text { (V-DEM) }\end{array}$} & 1 & $0.904 * *$ & $0.893 * *$ & $0.599 * *$ & $0.937 * *$ & $0.819 * *$ & $0.940 * *$ \\
\hline & & 71 & 71 & 71 & 71 & 69 & 69 \\
\hline \multirow[t]{2}{*}{ NEP } & & 1 & $0.834 * *$ & $0.671 * *$ & $0.896 * *$ & $0.772 * *$ & $0.944 * *$ \\
\hline & & & 71 & 71 & 71 & 69 & 69 \\
\hline \multirow[t]{2}{*}{ NMP } & & & 1 & $0.394 * *$ & $0.775 * *$ & $0.591 * *$ & $0.811 * *$ \\
\hline & & & & 71 & 71 & 69 & 69 \\
\hline \multirow[t]{2}{*}{$\mathrm{F}$} & & & & 1 & $0.661 * *$ & $0.796 * *$ & $0.802 * *$ \\
\hline & & & & & 71 & 69 & 69 \\
\hline \multirow[t]{2}{*}{ Polyarchy } & & & & & 1 & $0.914 * *$ & $0.966 * *$ \\
\hline & & & & & & 69 & 69 \\
\hline \multirow[t]{2}{*}{ Political Competition } & & & & & & 1 & $0.919 * *$ \\
\hline & & & & & & & 69 \\
\hline Fragmentation Indicator & & & & & & & 1 \\
\hline
\end{tabular}

Source: The authors with data from Barbosa 2015 and Coppedge et. al. 2017a.

**. The correlation is significant at the 0.01 (bilateral) level.

able, through factor analysis of the other independent variables. The models are shown in the tables below, and after that we have the analyzes (Tables 8 and 9).

The data corroborate the hypotheses that the greater the political and party fragmentation, the greater the tendency for the Judiciary to be empowered. For the test of the iSTF indicator, the variables NMP and Political Competition showed a positive impact on the indicator. As the values are exponentialized, the interpretation is that the increase of one unit in the minimum number of parties increases the chance of the Judiciary being strengthened by $11,43 \%$. The increase of one unit in political competition, on the other hand, increases the chance of $3.93 \%$. The fragmentation indicator is more complex, as it varies in standard deviations. Therefore, the increase of a standard deviation in the indicator produces a $45,46 \%$ chance increase in the iSTF indicator. The most intuitive is to stick with model two. In any case, both model 2 and model 3 show that the greater the political and party fragmentation, the stronger the judiciary becomes.

For Linzer \& Staton's 2015 LJI (Latent Judicial Independence) variable test, only one variable was statistically significant in the parsimonious model. As the linear model is simple, an increase of one unit in political competition produces an increase of 0.05 in the LJI unit, which ranges from 0.079 to 0.637 . Model three points out that the increase in a standard deviation in the fragmentation indicator produces an increase of 0.1494 in the LJI. In both cases it is quite intuitive to say that, again, but with other forms of measurement for the judiciary, the increase in fragmentation increases the indicators that measure the power of the judiciary.

For the test of the XCONST variable, again only the political competition variable was statistically significant, where the increase of one unit causes an increase of $23,03 \%$ in the dependent variable that measures the level of embarrassment of the judiciary over the Executive. The fragmentation indicator points to an increase of $53,21 \%$. 
Table 8 - Simple Linear (OLS) and Negative Binomial Regression Models

\begin{tabular}{|c|c|c|c|c|c|c|c|c|c|c|c|c|}
\hline \multirow{3}{*}{$\begin{array}{l}\text { Dependent Variables } \\
\text { [technique] } \\
\text { (model) }\end{array}$} & \multicolumn{3}{|c|}{ iSTF } & \multicolumn{3}{|c|}{$\begin{array}{l}\text { LJI (Latent Judicial Independ- } \\
\text { ence Index) }\end{array}$} & \multicolumn{3}{|c|}{ XCONST } & \multicolumn{3}{|c|}{ Judicial Indicator (V-DEM) } \\
\hline & \multicolumn{3}{|c|}{ [Negative Binomial] } & \multicolumn{3}{|c|}{ [MQO] } & \multicolumn{3}{|c|}{ [Negative Binomial] } & \multicolumn{3}{|c|}{ [MQO] } \\
\hline & (1) & (2) & (3) & (1) & (2) & (3) & (1) & (2) & (3) & (1) & (2) & (3) \\
\hline NEP & 0.9904 & & & $-0.0024 * *$ & & & 0.9644 & & & -0.0028 & & \\
\hline NMP & $1.0504 * * *$ & $1.1143 * * *$ & & -0.0081 & -0.0025 & & 0.9984 & 0.9799 & & $0.1547 * * *$ & $0.1480 * * *$ & \\
\hline $\mathrm{F}$ & $0.6515^{* *}$ & & & 0.044 & & & $4.8309 *$ & & & 0.1135 & & \\
\hline Polyarchy & $7.3364 * * *$ & & & $0.5395 * * *$ & & & 1.1236 & & & $2.0031 * * *$ & $2.1717 * * *$ & \\
\hline Political Competition & $0.9365^{* * *}$ & $1.0393 * * *$ & & $0.0263 * *$ & $0.0508 * * *$ & & $1.1675^{* *}$ & $1.2303 * * *$ & & 0.0134 & & \\
\hline Fragmentation Indicator & & & $1.4546^{* * *}$ & & & $0.1494 * * *$ & & & $1.5321 * * *$ & & & $0.9247 * * *$ \\
\hline Log Likelihood & -227.214 & -276.888 & -291.784 & & & & -102.504 & -104.314 & -122.951 & & & \\
\hline Pseudo R2 & 0.3291 & 0.1825 & 0.1385 & & & & 0.2735 & 0.2607 & 0.1515 & & & \\
\hline Prob. Chi2 & 1 & 0 & 0 & & & & 0.497 & 0.499 & 0.5 & & & \\
\hline R2 Ajustado & & & & 0.812 & 0.781 & 0.647 & & & & 0.9486 & 0.946 & 0.8552 \\
\hline Prob. (F) & & & & 0 & 0 & 0 & & & & 0 & 0 & 0 \\
\hline $\mathrm{N}$ & 69 & 69 & 71 & 64 & 64 & 65 & 64 & 64 & 65 & 61 & 71 & 71 \\
\hline
\end{tabular}

Source: The authors Barbosa data 2015 Coppedge et. al. 2017th and Linzer \& Staton 2015.

$* * p$-value $<0.05, * * * p$-value $<0.01$. 
Table 9 - Multinomial Regression Model (logit and probit)

\begin{tabular}{lcc}
\hline $\begin{array}{l}\text { Independent Variables } \\
\text { [técnica] }\end{array}$ & $\begin{array}{c}\text { Fragmentation Indicator } \\
\text { [Logit Multinomial] }\end{array}$ & $\begin{array}{c}\text { Fragmentation Indicator } \\
\text { [Probit Multinomial] }\end{array}$ \\
\hline XCONST_cat & - & - \\
weak(base category) & $3.586^{* *}$ & $2.6275^{* * *}$ \\
Medium & $4.7777^{* * *}$ & $3.6622^{* * *}$ \\
Strong & -25.48 & -25.383 \\
Log Likelihood & 0.5086 & \\
Pseudo R2 & 0 & 0.0001 \\
Prob. Chi2 & 65 & 65 \\
N & & \\
\hline
\end{tabular}

Source: The authors.

$* * p$-value $<0.05, * * * p$-value $<0.01$.

For the test of the factorized variable V-Dem Judicial Index, two variables were statistically important: NMP and polyarchy. It means that the increase of one unit in these variables increases by 0,1480 and 2,1717 standard deviations in the dependent variable, respectively. The fragmentation indicator, on the other hand, produces an increase of 0,9247 standard deviation. Then the test for the variable XCONST categorized in 3 levels.

For the ordinal variable, the multinomial technique (mlogit in STATA) was used and we chose the weak category to be the base result. In comparison to a weak constraint, there is more likely to be a medium constraint if there is an increase in party political fragmentation. There is even more likely to be a strong constraint compared to the weak category. The marginal effects also showed this. In the probit model, it reads practically the same way, there is a greater probability of medium constraint and even greater in strong constraint, compared with weak constraint, when a unit is increased in the dependent variable, which, because it is factored, this unit corresponds to a standard deviation, which is a very high value, but it is interesting to measure the impact (whether positive or negative, and its intensity) (Table 10).

Table 10 shows the marginal effects after the multinomial logit model, where it can be seen that the increase of one unit (standard deviation) in the fragmentation indicator, there is a $36,84 \%$ probability of having a strong constraint from the Judiciary over the Executive. In the probit model, the marginal effects are practically the same. There is a greater likelihood of a strong constraint compared to a weak one, when increasing a unit in the independent variable.

Table 10 - Marginal Effects

\begin{tabular}{lcccc}
\hline & Variable Fragmentation Indicator & Dy/dx & Standard Error & P>|z| \\
\hline logit & Weak & -0.3088 & 0.139 & 0.027 \\
& Medium & -0.0595 & 0.078 & 0.446 \\
& Strong & 0.3684 & 0.147 & 0.012 \\
probit & Weak & -0.4007 & 0.145 & 0.006 \\
& Medium & -0.0464 & 0.081 & 0.570 \\
& Strong & 0.4471 & 0.147 & 0.002 \\
\hline
\end{tabular}

Source: The authors. 
IV.1 Interactive Terms ${ }^{20}$

${ }^{20}$ To see more about the technique of interactive terms see Brambor et. al. (2006).
The regime variable ( $1=$ democracy, $0=$ dictatorship) was used only to measure the effect of party-political fragmentation on judicial empowerment in the different types of regime faced by Brazil. Thus, the interactive term was created from the independent variable that was shown to be statistically significant in all of the above models, so we opted for the fragmentation indicator (FragFac). The results of the fragmentation and regime interaction are shown in the Table 11.

It is evident that, when the period is democratic, the impact of fragmentation on judicial empowerment is even greater, and this is quite intuitive since dictators do not usually accept challenges, specially from within the three branches. Although there was a discreet judicial empowerment during dictatorial periods, the only actor with the capacity to file constitutional actions was the Attorney General, with the free and exclusive appointment of the President of the Republic throughout the dictatorial regime, thus controlling the demands presented to the Supreme Court. This is more evident in the graph below.

The image on the left shows the interaction of political fragmentation with the regime impacting the iSTF indicator, while the image on the right shows the impact of fragmentation on the V-Dem Judicial Index indicator. In both cases, it is possible to verify the effect of the political regime on the empowerment of the Judiciary. Finally, based on the data from Barbosa 2015, we verified a bank with 23 constitutional amendments that modified the powers and prerogatives of the Judiciary in the Brazilian constitutions from 1891 to 2013. The following table organizes this information (Graph 4).

In relation to who contributed most to amend constitutional texts to empower the Judiciary, the following table of cross references summarizes the data (Table 12).

Of the 22 amendments, the Executive was the author of 54,5\%. In the dictatorial regime this participation was even greater, remembering that during the dictatorial regime, the control of ABSTRACT constitutionality was the exclusive authorship of the Attorney General, who was the exclusive and free nomination of the President of the Republic, having this total control over theABSTRACT review. This shows that not only the Legislative, but mainly

Table 11 - Impact of Fragmentation on Empowerment in different regimes (interactive terms)

\begin{tabular}{|c|c|c|c|}
\hline $\begin{array}{l}\text { Dependent Variable } \\
\text { [technique] }\end{array}$ & Regime & $\begin{array}{c}\text { iSTF } \\
\text { [Negative Binomial] } \\
\end{array}$ & $\begin{array}{c}\text { Judicial Indicator (V-DEM) } \\
{[\mathrm{MQO}]} \\
\end{array}$ \\
\hline \multicolumn{4}{|l|}{ Interactive Term } \\
\hline \multirow[t]{2}{*}{ Fragmentation Indicator } & 0 (dictatorship) & $1.1177 * *$ & $0.7130 * * *$ \\
\hline & 1 (democracy) & $1.6947 * * *$ & $1.0606^{* * *}$ \\
\hline Log Likelihood & -286.326 & & \\
\hline Pseudo R2 & 0.1775 & & \\
\hline Prob, Chi2 & 0 & & \\
\hline R2 Adjusted & 0.8675 & & \\
\hline Prob, (F) & 0 & & \\
\hline $\mathrm{N}$ & 71 & 71 & \\
\hline
\end{tabular}

Source: The authors.

$* * p$-value $<0.05, * * * p$-value $<0.01$. 
Graph 4 - Marginal Effect of Political Fragmentation on Judicial Empowerment
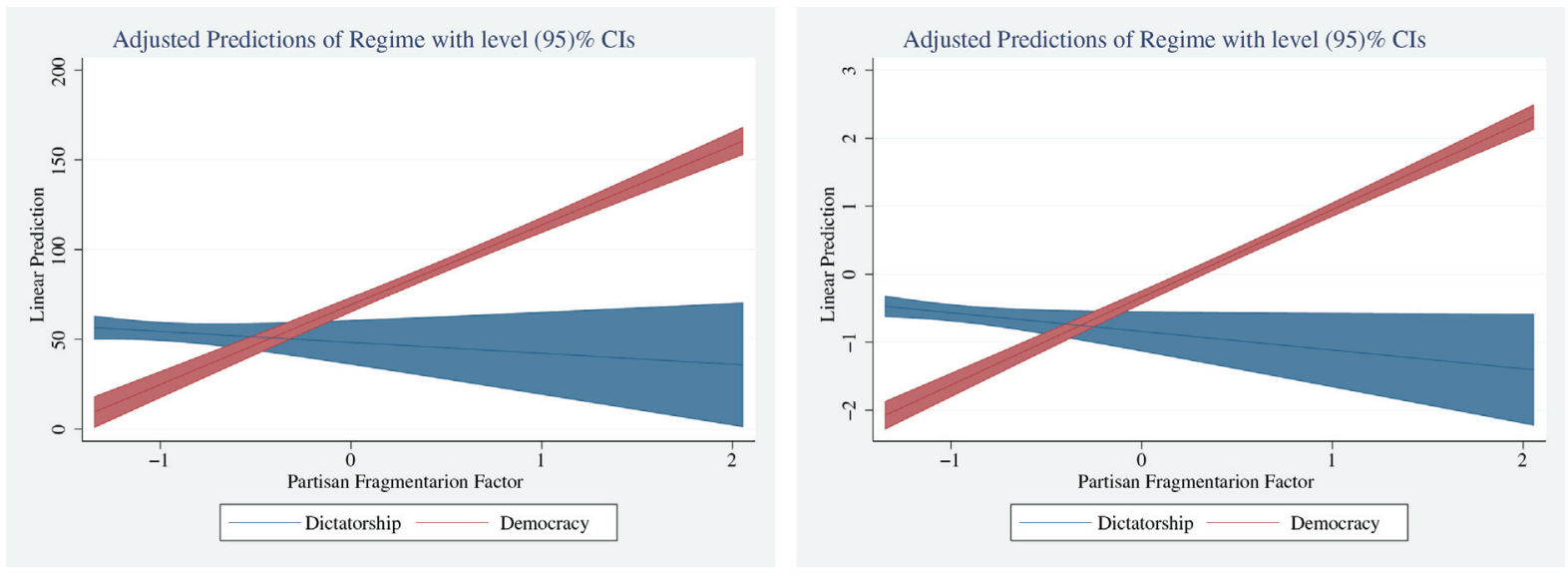

Source: The authors, based on Barbosa 2015.

Table 12 - Authorship and Regime by constitutional amendments from 1891 to 2013

\begin{tabular}{lccc}
\hline & Legislative & Executive & Total \\
\hline Democracy & $5(50)$ & $5(50)$ & $10(100)$ \\
Dictatorship & {$[50]$} & {$[41.6]$} & \\
& $5(41.6)$ & $7(58.4)$ & $12(100)$ \\
Total & {$[50]$} & {$[58.4]$} & \\
& $10(45.5)$ & $12(54.5)$ & $22(100)$ \\
& {$[100]$} & {$[100]$} & {$[100]$} \\
\hline
\end{tabular}

Source: The authors, based on data from Barbosa 2015.

Note: Lines frequencies are in parentheses and columns frequencies are in brackets.

the Executive had a lot of interest and initiative to increase the prerogatives of the Judiciary.

\section{Conclusions}

If, in the resumption of democratic discussion in post-absolutism models Parliament was the central institution, there is no doubt that in the post-war period the Judiciary came to play a prominent role, especially in times of political crisis, where political alignment (or necessary coalitions) had become a key point for the proper functioning of democracies. There is no denying that today the Supreme Courts have become a key player in the decision-making process, given the inability of the elected powers to resolve political impasses. What was in Montesquieu's words "almost nothing", or according to Aliomar Baleeiro (1968) "an unknown”, became the Queen of a chess game.

In Brazil, this process, although consolidated by the 1988 Constitution, continued to evolve, giving the Supreme Federal Court the chance to exercise a decision-making capacity not provided for in the constitutional text. The models were forceful in demonstrating that party fragmentation has a positive and statistically significant impact on the increase in power of the Supreme Federal Court and this impact is stronger in the democratic period when compared to the dictatorial period. It was also proven that the increase in the power of the STF was mainly due to constitutional amendments, of which the Executive was the author of most. As previously mentioned, other variables may have a relative 
weight in explaining specific decisions, such as the Courts' own endogenous decision-making dynamics, an exclusive source of self-empowerment.

The current moment of political crisis and the increasingly attentive eyes to the decisions of the ministers of our supreme court corroborate the growing trajectory of institutional empowerment, which authorizes the court to decide peremptorily, and not only within the process of drafting public policies, but also about the government's own definition and the freedom of its members involved in scandals. The impasses that the country is experiencing recently increase the demand for decisions of the Supreme Federal Court. Therefore, the solution that has been sought to circumvent (by-pass) the problems of party fragmentation and political uncertainties is through the judicial system, as a kind of insurance policy. And all of this happened with the support, consent and silence of the incumbents.

Leon Victor de Queiroz Barbosa (leon.victorqueiroz@ufpe.br) is PhD in Political Science from the Federal University of Pernambuco (UFPE) and Professor at the Political Science Department at UFPE.

Ernani Carvalho (ernani.carvalho@ufpe.br) is PhD in Political Science from the University of São Paulo (USP) and Professor at the Political Science Department at UFPE.

\section{References}

Barbosa, L. V. de Q., 2015. O Silêncio dos Incumbentes: fragmentação partidária e empoderamento judicial no Brasil. Tese de Doutorado. Recife: Universidade Federal de Pernambuco.

Baleeiro, A., 1968. O Supremo Tribunal Federal, esse outro desconhecido. Rio de Janeiro: Forense.

Berkson, J., 1944. Application of the logistic function to bioassay. Journal of the American Statistical Association, 39 (227), pp. 357-365. DOI: 10.1080/01621459.1944.10500699

Brambor, T.; Clark, W. R. \& Golder, M., 2006. Understanding Interaction Models: Improving Empirical Analysis. Political Analysis, 14(1), pp.63-82. DOI: 10.1093/pan/mpi014

Carvalho, E., 2007. Revisão judicial e judicialização da política no direito ocidental: aspecto relevantes de sua gênese e desenvolvimento. Revista Sociologia e Política, s/v, nº 28, pp.161-179. DOI: 10.1590/S1517-45222010000100007

Coelho, R. C., 1999. Partidos Políticos: Maiorias Parlamentares e Tomada de Decisão na Constituinte. Tese de Doutorado. São Paulo: Universidade de São Paulo.

Coppedge, M. et. al., 2017a. V-Dem [Country-Year/Country-Date] Dataset v7.1.

Coppedge, M. et. al., 2017b. V-DEM Codebook v7.1 - Varieties of Democracy (V-Dem) Project. University of Gothenburg.

Couso, J. A.; Huneeus, A. \& Sieder, R. (orgs.), 2010. Cultures of Legality: Judicialization and Political Activism in Latin America. New York: Cambridge University Press.

Da Ros, L., 2017. Em que Ponto Estamos? Agenda de Pesquisa sobre o Supremo Tribunal Federal no Brasil e nos Estados Unidos. In F. Engelmann, (org.). Sociologia Política das Instituições Judiciais. Porto Alegre: Editora UFRGS.

Dahl, R., 1957. Decision-making in a Democracy: The Supreme Court as a National Policy-Maker. Journal of Public Law, s/v, n6, pp. 279-295.

David, R., 2002. Os grandes sistemas do Direito contemporâneo. São Paulo: Martins Fontes.

Dyke, G. V. \& Petterson, H. D., 1952. Analysis of factorial arrangements when the data are proportions. Biometrics, 8(1), pp. 1-12. DOI: $10.2307 / 3001521$

Elster, J., 2000. Ulisses Liberto - Estudos sobre Racionalidade, Pré-compromissos e Restrições. São Paulo: Editora Unesp.

Feigl, P. \& Zelen, M., 1965. Estimation of exponential survival probabilities with concomitant information. Biometrics. 21(4), pp. 826-838. DOI: 10.2307/2528247

Ferejohn, John, 2002. Judicializing Politics, Politicizing Law. Law and Contemporary Problems. 65(3), pp. 41-68.

Figueiredo Filho, D. B. \& Silva Júnior, J. A. da, 2010. Visão Além do Alcance: uma introdução à análise fatorial. Opinião Pública, 16, (1), pp. 160-185. DOI: 10.1590/S0104-62762010000100007

Garson, G. D., 2009. "Factor Analysis" from Statnotes: Topics in Multivariate Analysis [online]. Disponível em < http://faculty.chass.ncsu.edu/garson/pa765/statnote.htm > . Acesso em 10.ago.2020.

Ginsburg, T., 2003. Judicial Review in New Democracies. Cambridge: University Press.

Hair, J. F.; Anderson, R. E.; Tatham, R. L. \& Black, W. C., 2005. Análise Multivariada de Dados. Rio de Janeiro: Bookman.

Hall, Peter A. \& Taylor, Rosemary C., 2003. As Três Versões do Neoinstitucionalismo. Lua Nova, s/v, nº 58, pp. 193-224. DOI: 10.1590/S0102-64452003000100010

Hattam. V. C., 1993. Labor Visions and State Power. The Origins of Business Unionism in the United States. Princeton: University Press.

Herrera, C. M., 1994. La polémica Schmitt-Kelsen sobre el guardián de la Constitución. Revista de Estudios Politicos, s/v, nº6, pp. 195-227. 
Ingram, M. C., 2015. Judicial Power in Latin America. Latin American Research Review, 50(1), pp. 250-260.

Ingram, M. C., 2016. Crafting Courts in New Democracies: The Politics of Subnational Judicial Reform in Brazil and Mexico. New York: Cambridge University Press.

Koerner, A., 2013. Ativismo Judicial? Jurisprudência constitucional e política no STF pós-88. Novos Estudos - CEBRAP, s/v, no 96, pp. 69-85. DOI: 10.1590/S0101-33002013000200006

Koopmans, T., 2003. Courts and Political Institutions - A Comparative View. New York: Cambridge University Press.

Lijphart, A., 2003. Modelos de Democracia: desempenho e padrões e governo em 36 democracias. Trad. Roberto Franco. Rio de Janeiro: Civilização Brasileira.

Linzer, D. A. \& Staton, J. K., 2015. A Global Measure of Judicial Independence. Journal of Law and Courts, 3(2), pp. $223-256$. DOI: $10.1086 / 682150$

Melo, M. A., 2007. Hiperconstitucionalização e Qualidade da Democracia - Mito e Realidade. In C. R. Melo \& M. A. Sáez (orgs). Democracia Brasileira: Balanços e Perspectivas para o Século 21. Belo Horizonte: Ed. UFMG, pp. 237-265.

Maravall, J.M. \& Przeworski, A., 2003. Democracy and the Rule of Law. New York: Cambridge University Press.

Negretto, G. L., 2013. Making Constitutions: Presidents, Parties and Institutional Choice in Latin America. New York: Cambridge University Press.

Nelder, J. A. \& Wedderburn, R. W. M., 1972. Generalized Linear Models. Journal of the Royal Statistics Society, 135(3) pp. 370-384. DOI: $10.2307 / 2344614$

Pallant, J., 2007. SPSS Survival Manual. London: Open University Press.

Rae, D., 1971. The Political Consequences of Electoral Laws. New Haven: Yale University Press.

Shugart, M. S. \& Carey, J. M., 1992. President and Assemblies: Constitutional Design and Electoral Dynamics. New York: Cambridge University Press.

Sweet, A. S., 2000. Governing with Judgers: Constitutional Politics in Europe. Oxford: University Press.

Tate, N. C, \& Vallinder, T., 1995. The Global Expansion of Judicial Power. New York: University Press.

Teorell, J. et. al., 2016. Measuring Electoral Democracy with V-Dem Data: Introducing a New Polyarchy Index - V-Dem Working Paper 2016:25. University of Gothenburg.

O Supremo Tribunal Federal como a rainha do jogo de xadrez: fragmentação partidária e empoderamento judicial no Brasil

RESUMO Introdução: Este artigo analisa o processo de empoderamento do Supremo Tribunal Federal (STF) do Brasil entre 1945 e 2015. O objetivo é explicar o que tornou o STF tão poderoso institucionalmente e como isso ocorreu. Estudos sobre a expansão global do poder judicial apontam uma multiplicidade de causas para explicar esse fenômeno, mas pesquisas recentes vêm indicando a fragmentação político-partidária como a principal causa do empoderamento judicial. O presente trabalho testa a hipótese de que quanto maior a fragmentação partidária, mais poder institucional o STF possuirá. Materiais e Métodos: Como variável dependente, foi criado um indicador sintético que mensura o poder institucional do Supremo Tribunal Federal ano a ano. As variáveis independentes mensuraram anualmente a composição partidária da Câmara dos Deputados para o mesmo período. Além dessas variáveis, foram importadas outras medidas da base de dados do V-Dem. Para essa análise foram utilizados modelos lineares simples, lineares generalizados e multinomiais. Resultados: Foi identificado um alto impacto da fragmentação partidária no empoderamento institucional do STF. Em todos os testes, a fragmentação partidária aumentou as chances de empoderamento institucional do Poder Judiciário brasileiro. Discussão: As reformas exógenas que geraram esse empoderamento se deram com o apoio do Poder Executivo e com a leniência do Poder Legislativo, transformando a Suprema Corte brasileira na Rainha do jogo de xadrez institucional nacional.

PALAVRAS-CHAVE: Poder Judiciário; fragmentação partidária; empoderamento judicial; Supremo Tribunal Federal; multinomial; análise fatorial.

This is an Open Access article distributed under the terms of the Creative Commons Attribution Non-Commercial License which permits unrestricted non-commercial use, distribution, and reproduction in any medium provided the original work is properly cited.

A produção desse manuscrito foi viabilizada através do patrocínio fornecido pelo Centro Universitário Internacional Uninter à Revista de Sociologia e Política. 